\title{
LABORATORY TESTS IN ADDITION TO THE ALVARADO SCORE IN THE MANAGEMENT OF ACUTE APPENDICITIS IN SCHOOL-AGE CHILDREN
}

\author{
Astra Zviedre ${ }^{1,2, \#}$, Arnis Engǵelis ${ }^{1,2}$, Pēteris Tretjakovs ${ }^{3}$, Irisa Zīe ${ }^{4,5}$, \\ and Aigars Pētersons ${ }^{1,2}$

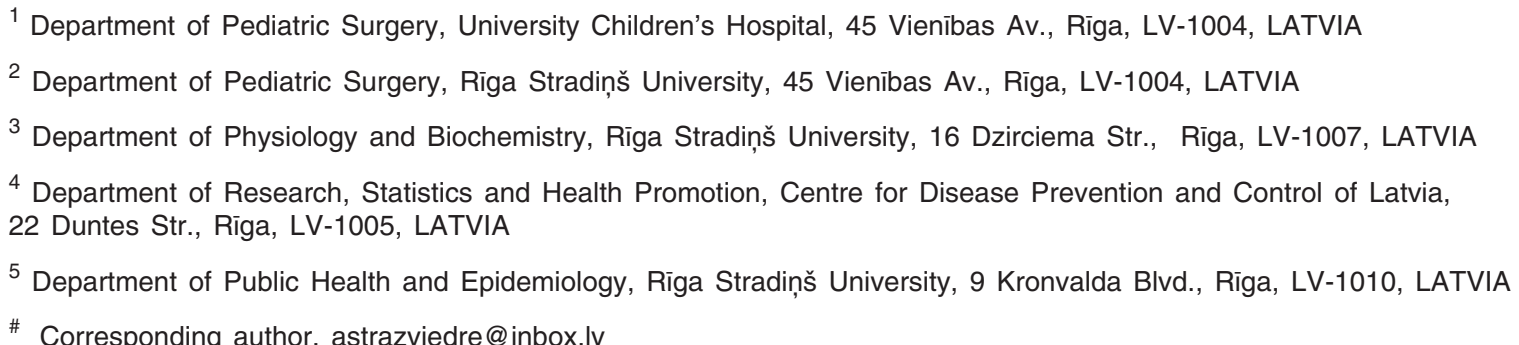

Contributed by Aigars Pētersons

\begin{abstract}
The aim of the study was to determine whether the Alvarado score (AS) together with laboratory tests could be used to distinguish patients with acute appendicitis $(A A)$ from acute mesenteric lymphadenitis (AML). Fifty-seven patients (7-18 years) with suspected $A A$ were included in the prospective study (October 2010 - October 2013). Thirty-one patients underwent surgery for $A A$ and 26 were not treated surgically and were diagnosed AML on ultrasonography. AS, white blood cell count (WBC), $C$ - reactive protein (CRP) and serum cytokines (EGF, IL-10, IL-12(p70), IL-1 $\beta$, IL-4, IL-6, IL-8, IL-17, MCP-1, TNF- $\alpha$ ) were obtained on admission and were compared between groups. Mean age of the 57 patients was 12.9 (SD 3.2). Accuracy (AR) for AS $\geq 7$ alone was $73.7 \%$ for AA. Modified AS with certain serum cytokines seemed to be a reliable tool for initial differential diagnosis between $A A$ and $A M L$ in school-age children. Based on these results, $A S \geq 7$, $W B C \geq 10.7 \times 103 / \mu \mathrm{L}$ and serum $\mathrm{IL}-6 \geq 4.3 \mathrm{pg} / \mathrm{mL}$ assessed altogether will yield more sensitivity for AA. Also for further advanced diagnostics, we propose to take into account the serum IL-6, IL-8, MCP-1, CRP cut-off levels in the differential diagnosis between complicated and uncomplicated $A A$ to decide whether the treatment should be conservative or surgical.
\end{abstract}

Key words: appendicitis, mesenteric lymphadenitis, Alvarado score, serum cytokines.

\section{INTRODUCTION}

While the established state tertiary healthcare system involves widely available modern visual methods of diagnostics as well as application of broad-spectrum antibiotics in treatment, the assessment of acute abdominal pain syndrome in paediatrics is really challenging. All over the world, including Latvia, some of the most common acute abdominal inflammation processes attributed to children are acute appendicitis (AA) and acute mesenteric lymphadenitis (AML). In the case of the above-mentioned health problems, it is necessary to ensure timely diagnosis and appropriate treatment. Clinical presentation of AA and AML is often similar. In the case of AML, treatment is always con- servative and does not require immediate hospitalisation of the patient. However, a patient with AA could be provided with or without emergent surgical intervention. Timely diagnostics of AA and AML improves the quality of life of patients in the future. It reduces the likelihood of negative appendectomy, rate of appendix perforation, shortens the hospitalisation period, as well as speeds up the recovery process and reduces the risk of developing intestinal impenetrability at the late postoperative period due to complicated intra-abdominal infection (Myers et al., 2012). State Ltd Children's Clinical University Hospital (State Ltd CCUH) patient data (2000-2009) show that on average from $18.8 \%$ to $21 \%$ of cases had a delayed start of treatment, and these required not only the treatment of the dis- 
ease itself, but also the treatment of complications (Surna et al., 2011). In future, the determination of serum inflammatory mediators of the cytokine group (SIMCG) could serve as indispensable diagnostic markers of AA and AML in children aged 7 to 18 years, which would shorten the differential time of diagnosis and facilitate the choice of an appropriate treatment method (Õzdamar et al., 2018). The Alvarado score (AS), being one of the AA diagnostic methods, has been previously used by some paediatric hospitals in Europe and the United States. It could be used as a sufficiently sensitive method together with laboratory values and ultrasonography (US) examination for early identification of AA cases in children (Ünlüer et al., 2016; Peyvasteh et al., 2017). The incidence of AA complications and the number of negative appendectomies were used to show the quality of national health care system for children with AA. Taking into account the analysed clinical, laboratory and radiological data of children with AA and AML, an AA prediction and action algorithm was have developed for children aged 7-18 with suspicion of AA. The major scientific novelty of the study is the importance of SIMCG in differential diagnosis and the link of biomarkers with other methods of AA and AML case diagnosis in children in the 7 to 18 years of age.

\section{MATERIALS AND METHODS}

The framework of the research was a mixed type prospective case-control study. The study was carried out at the state tertiary healthcare institution, State Ltd CCUH, Paediatric Surgery Clinic and Central Laboratory; Rīga Stradiňš University, Departments of Paediatric Surgery, Human Physiology and Biochemistry in the period from 2010 to 2013. The research was approved by the decision of State Ltd CCUH Medical Committee for Research Ethics. All children and parents/guardians signed a written consent on inclusion of data in the study.

Selection of subject data. Study patients had to meet the following inclusion criteria: children aged between 7 and 18 years and hospitalised in the State Ltd CCUH, parental or legal guardian written informed consents as applicable by local laws and regulations, supported evidence of AA in the abdominal ultrasonography (US) (appendix $7 \mathrm{~mm}$ and more diameter and is not compressible) or evidence of AML in the US ( 3 and more enlarged mesenteric lymph nodes, short axis $10 \mathrm{~mm}$ and more), and at least one of the clinical symptoms: abdominal pain, nausea, rebound tenderness, fever $\geq$ $37.3{ }^{\circ} \mathrm{C}$, white blood cell (WBC) count $10 \times 10^{3} / \mu \mathrm{L}$ ). If the patient was a female of child-bearing potential, a negative pregnancy test was mandatory. Exclusion criteria were prior abdominal surgery, chronic gastrointestinal illness or abdominal pain, diabetes, septic shock, known immunosuppression, infections originating from the female genital tract, a perforation of the upper gastrointestinal tract and systemic antibacterial treatment within the previous seven days, non-steroidal inflammatory drug and hormonal treatment within 30 days. In order to achieve a prospective selection of data and meet the objectives of the study regard- ing the role of SIMCG in AA and AML diagnosis in children, there were 57 patients prospectively selected according to the study inclusion criteria out of 178 study subjects hospitalised in the State Ltd CCUH Paediatric Surgery Department; 31 of them were patients with AA (AA group) and 26 patients with AML (AML group). To obtain a more detailed analysis, the 31 AA patients were divided into uncomplicated and complicated groups. In order to assess the role of serum cytokines in AA and AML diagnosis and determine their reference values, 17 patients with elective non-inflammatory surgical disease (C group) were included in the study. All of the patients suspected with AA were checked by a paediatric surgeon in the Emergency Department; the Alvarado score was used, blood samples were taken and examined and/or abdomen cavity organs were examined by US.

SIMCG measurements. Blood samples for the determination of cytokines were taken from the patients with AA and patients in the $\mathrm{C}$ group three times: one hour before the surgical intervention (before the onset of incision), and 24 and 72 hours after the surgical treatment. For those with AML, blood samples also were collected three times: as soon as the patients were admitted to the hospital (before any treatment was given), and 24 and 72 hours after patient hospitalisation. Peripheral venous blood samples were collected from an antecubital vein drawn with a sterile syringe, and transferred to a centrifuge tube. The samples were allowed to clot for 20 to $30 \mathrm{~min}$ at room temperature. Serum was separated by centrifugation at $4{ }^{\circ} \mathrm{C}$ for $20 \mathrm{~min}$ at $1600 \times \mathrm{g}$. All specimens were immediately aliquoted, frozen and stored at $-80{ }^{\circ} \mathrm{C}$. Serum (interleukin-10 (IL-10), interleukin-12(p70) (IL-12(p70)), interleukin-1 beta (IL-1 $\beta$ ), interleukin-4 (IL-4), interleukin-6 (IL-6), interleukin-8 (IL-8), interleukin-17 (IL-17), monocyte chemoattractant protein-1 (MCP-1), epithelial growth factor (EGF), tumour necrosis factor- $\alpha$ (TNF- $\alpha)$ ) levels were evaluated by using Milliplex Map kit (Human Cytokine / Chemokine Magnetic Bead Panel) for Luminex xMAP Technology (Luminex 200, Luminex Corporation, Austin, Texas, United States). The minimum detectable levels of these assay kit were 3.2 $\mathrm{pg} / \mathrm{mL}$ for all cytokines.

Statistical analysis. Chi-square and Fisher's exact tests were used for data analysis of the studied population subgroups compared in $2 \times 2$ tables. The Kruskal-Wallis $\mathrm{H}$ test was applied for comparison of three or more groups that were independent. For cases where the test indicated statistically significant differences $(p<0.05)$, the Mann-Whitney $\mathrm{U}$ test was used for paired comparison of groups (Peacok and Peacok, 2011; pp. 141, 303). In order to assess significance and accuracy of AA and AML cases diagnosed by the methods used in the study (Alvarado score, laboratory and US tests), sensitivity and specificity, positive predictive value (PPV) and negative predictive value (NPV) were calculated (Peacok and Peacok, 2011; pp. 340-349). Receiver Operating Characteristic (ROC) curves were analysed for SIMCG, WBC, CRP concentration cut-off value one hour before the surgery and at the $24^{\text {th }}$ and $72^{\text {nd }}$ hour after sur- 
gery in the case of AA, as well as at the time of hospitalisation after AML was diagnosed and at the $24^{\text {th }}$ and $72^{\text {nd }}$ hour after the initiation of the treatment of AML cases. The area under the curve (AUC) with the value from 0.5 to $1.0-\mathrm{a}$ perfect test, was used to compare the quality of the cut-off value. Striving for accuracy, the likelihood ratio (LR) was used to describe the diagnostic prediction level of a particular parameter (SIMCG, WBC, CRP) in AA cases. Statistical analyses were performed using SPSS for Windows 20.0, statistical data processing programme (SPSS Inc., United States).

\section{RESULTS}

A total 178 patients underwent consultations with our ED during the study period. Of them, 121 children had pathologies other than AA and were excluded. There were a total of 57 patients with mean age of 12.9 (SD 3.2), who met the inclusion criteria. Thirty-five $(61.4 \%)$ were boys. Of these, 31 had confirmed AA and had undergone an appendectomy. Of the remaining 26 patients were diagnosed AML on USG. Comparison of patient characteristics by the Alvarado score and findings between groups are summarised in Figure 1. Statistically significant differences in the incidence rates between the AA and AML groups were observed according to Alvarado score, which is based on subjective and objective criteria: nausea, vomiting, and positive peritoneal irritation. The most common scale value of $\leq 4$ points $-42.3 \%$ (95\% CI 25.5-61.1) $(\mathrm{n}=11)$ was observed in the case of AML, while for AA the most common value was 7-8 points - 45.2\% (95\% CI 29.2-62.2) $(\mathrm{n}=14)$. An Alvarado score with value $9-10$ points was observed only in the case of AA - 25.8\% (95\% CI 13.7-43.2) $(n=8)$. Regarding precision of the Alvarado score as a diagnostic method for AA, the sensitivity, specificity, PPV and NPV of the score value of $\geq 7$ points were $71.0 \%, 76.9 \%, 78.6 \%$ and $67.0 \%$, respectively (AUC $=0.737$ (95\% CI 61.0-83.4) with LR+3.1, and LR- 3.8 and $p=0.002$ ). US examination of all study patients with AA and AML was performed. The sensitivity, specificity, PPV and NPV of this method for the diagnosis $(\mathrm{AUC}=0.719(95 \%$ CI 59.2-81.9) and $p=0.007)$. More detailed analysis of the US data for AA patients showed that of AA were $64.5 \%, 76.9 \%, 70.0 \%$ and $64.5 \%$, respectively

presence of coprolite was more frequent in complicated AA than in uncomplicated AA cases: $30.0 \%$ (95\% CI 10.8 60.3 ) versus only $19 \%$ (95\% CI 7.7-40.0), respectfully. Initially, WBC and IL-6 were shown to be a valuable diagnostic tool in AA. The results of ROC analysis showed that the optimal IL-6 cut-off level for AA patients one hour before surgery was $4.3 \mathrm{pg} / \mathrm{mL}$ with $67.7 \%$ sensitivity and $76.9 \%$ specificity, respectively (AUC $=0.77$ (95\% CI 0.64-0.89) with $\mathrm{LR}+2,93$, LR -0.42 and $p=0.001)$, and the WBC cut-off level was $10.7 \times 10^{3} / \mu \mathrm{L}$ with $74.2 \%$ sensitivity and $53.8 \%$ specificity, respectively $(\mathrm{AUC}=0.72(95 \% \mathrm{CI}$ $0.58-0.85)$ with LR +1.6, LR- 0.5 and $p=0.005)$. Mostly other laboratory markers in serum had very similar values in both AA and AML patient groups; the AUC values ranged from 0.4 to 0.6 , which indicates low sensitivity and specificity of a particular marker ratio. There was a statistically significant difference between $\mathrm{AA}$ and $\mathrm{C}$ groups for all three measurements in terms of the following cytokines concentration as IL-10 and IL-6. The concentration of serum cytokines IL-6 and IL-10 at the first time of measurement was significantly higher for the AA group in comparison to AML patients (Table 1). In order to obtain a more thorough analysis of the results, SIMCG were analysed in AA patients. Cytokine median values taken one hour before surgery, at $24^{\text {th }}$ and $72^{\text {nd }} \mathrm{h}$ after surgery were relatively higher in patients with complicated AA than for patients with uncomplicated AA. Table 2 gives median concentra-

\section{Table 1}

SIMCG CONCENTRATIONS IN STUDY GROUPS AT THE FIRST MEASUREMENT

\begin{tabular}{c|cccc|c|c}
\hline $\begin{array}{c}\text { SIMCG, } \\
\mathrm{pg} / \mathrm{ml}\end{array}$ & $\begin{array}{c}\text { AA group, } \\
\mathrm{n}=31\end{array}$ & $\begin{array}{c}\text { AML group, } \\
\mathrm{n}=26\end{array}$ & $\begin{array}{c}\mathrm{C} \text { group, } \\
\mathrm{n}=17\end{array}$ & $\begin{array}{c}\text { Kruskal- } \\
\text { Wallis test, } \\
p \text { value }\end{array}$ & $\begin{array}{c}\text { Mann- } \\
\text { Whitney U } \\
\text { test, } p \text { value }\end{array}$ \\
\hline IL-10 & 6.1 & 3.2 & 3.2 & 0.005 & $0.02^{*}$ \\
& $(3.2-17.0)$ & $(3.2-3.2)$ & $(3.2-3.2)$ & & $0.005^{* *}$ \\
IL-6 & 8.0 & 3.2 & 3.2 & 0.0003 & $0.01^{*}$ \\
& $(3.2-97.6)$ & $(3.2-3.2)$ & $(3.2-11.7)$ & & $0.0002^{* *}$
\end{tabular}

SIMCG, serum inflammatory mediators of cytokine group; AA, patients with acute appendicitis; AML, patients with acute mesenteric lymphadenitis; C, control group; IL-10, interleukin 10; IL-6, interleukin 6; ${ }^{*} p<0.05$ AA group compared to $\mathrm{C}$ group; ${ }^{*} p<0.05$ AA group compared to AML group

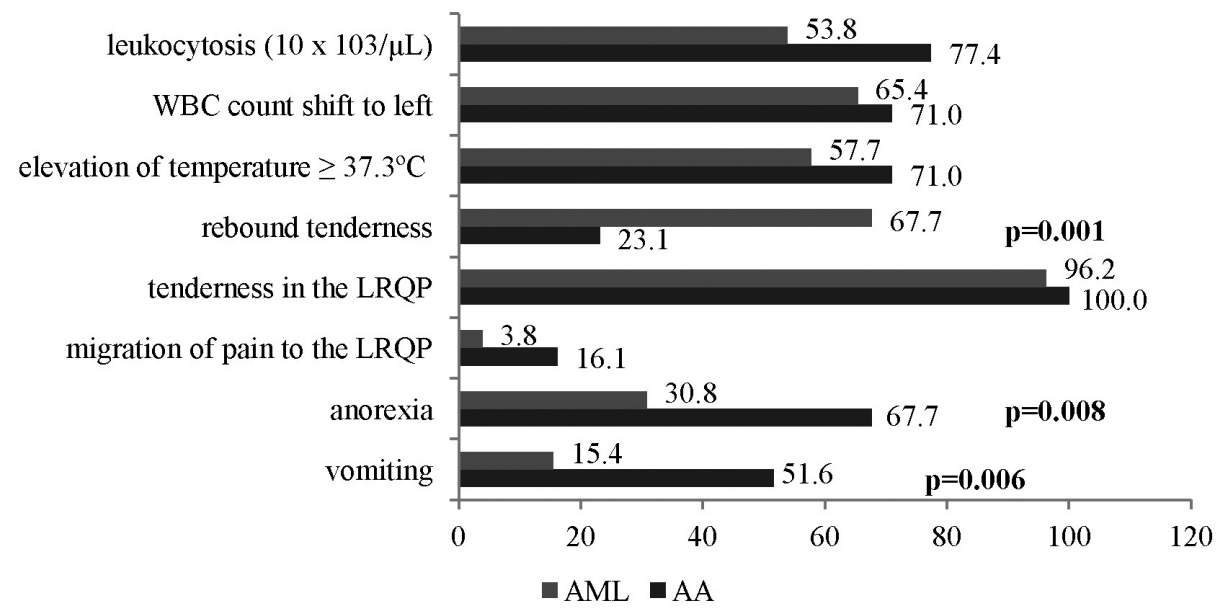

Fig. 1. Alvarado score incidence rate in AA and AML, \%

AA, patients with acute appendicitis; AML, patients with acute mesenteric lymphadenitis; LRQP, right lower quadrant pain, WBC, white blood cell count; $p$ value 
Table 2

CYTOKINE CONCENTRATION IN SERUM (MEDIAN (25-75 PERCENTILE)) ONE HOUR PRIOR TO SURGERY IN PATIENTS WITH UNCOMPLICATED AND COMPLICATED AA, pg/mL

\begin{tabular}{l|c|c|c}
\hline \multirow{2}{*}{$\begin{array}{c}\text { SIMCG, } \\
\mathrm{pg} / \mathrm{ml}\end{array}$} & \multicolumn{2}{|c|}{ Median (25 and 75 percentile) } & \multirow{2}{*}{$\begin{array}{c}p \text { value } \\
\text { Mann- }\end{array}$} \\
\cline { 2 - 3 } & $\begin{array}{c}\text { uncomplicated AA, } \\
\mathrm{n}=21\end{array}$ & $\begin{array}{c}\text { complicated AA, } \\
\mathrm{n}=10\end{array}$ & $\begin{array}{c}\text { Whitney test } \\
\text { IL-6 }\end{array}$ \\
\hline IL-8 & $8.4(3.2-15.6)$ & $257.8(67.5-343.3)$ & 0.001 \\
MCP-1 & $341.3(215.1-563.4)$ & $653.9(468.9-2165.8)$ & 0.03
\end{tabular}

SIMCG, serum inflammatory mediators of cytokine group; AA, patients with acute appendicitis, IL-8, interleukin 8, IL-6, interleukin 6; MCP-1, monocyte chemoattractant protein-1

tions of IL-6, IL-8 and MCP - 1 in serum obtained one hour before surgery in the AA group, and indicates significant differences between uncomplicated and complicated subgroups. An increase of IL-6, IL-8 and MCP-1 concentrations was observed within the first 12 hours in both AA groups, with a greater increase of concentration in AA complicated cases. To determine the role of SIMCG in the diagnosis of AA, the ROC analysis was used to compare the cut-off value AUC, taking $\geq 0.7$ as the basis, which is the lowest value of the test that can be considered high-quality regarding sensitivity and specificity. ROC analysis indicated the significant cytokine IL-6 and IL-8 serum concentrations (AUC $\geq 0.7$ ) in patients with complicated AA one hour before surgery and at the $24^{\text {th }}$ hour after surgery, as well as the concentration of MCP-1 before surgery (Figs. 2 and 3). One hour before surgery the IL-6 concentration cut-off level was $39.2 \mathrm{pg} / \mathrm{mL}$ in complicated AA cases, with sensitivity of $80.0 \%$, specificity $81.0 \%(\mathrm{AUC}=0.86(95 \%$ CI 0.69-1.0) with LR + 4.2, LR- 0.3 and $p=0.001$ ), while the IL- 6 concentration cut-off level at the $24^{\text {th }}$ hour after surgery was $9.4 \mathrm{pg} / \mathrm{mL}$ with sensitivity $90 \%$, specificity $76.2 \%$, respectively (AUC $=0.85$ (95\% CI 0.69-1.0) with $\mathrm{LR}+3.8, \mathrm{LR}-0.1$ and $p=0.002$ ) (Fig. 1). One hour before surgery the IL- 8 concentration cut-off level was $12.3 \mathrm{pg} /$ $\mathrm{mL}$ in the case of complicated AA with AUC $=0.76(95 \%$ CI $0.57-0.95 ; p=0.02$ ), sensitivity $90.0 \%$, specificity $66.7 \%$, and LR +2.7, LR- 0.2 , while the IL- 8 concentration cut-off level at the $24^{\text {th }}$ hour after the operation was $11.6 \mathrm{pg} / \mathrm{mL}$ with sensitivity and specificity of $90 \%$ and $61.9 \%$, respectively (AUC $=0.78(95 \%$ CI $0.61-0.94)$ with $\mathrm{LR}+2.4, \mathrm{LR}-0.2$ and $p=0.01$ ) (Fig. 2). One hour before surgery, the MCP-1 concentration cut-off level was 400.2 $\mathrm{pg} / \mathrm{mL}$ in complicated AA, with AUC $=0.75(95 \% \mathrm{CI}$ $0.55-0.96 ; p=0.03)$, sensitivity $90.0 \%$, specificity $66.7 \%$, $\mathrm{LR}+2.7, \mathrm{LR}-0.2$. The CRP concentration in serum at the acute-phase significantly differed between uncomplicated and complicated AA. One hour before surgery the serum CRP concentration cut-off level was $8.4 \mathrm{mg} / \mathrm{L}$ in complicated AA case, with sensitivity and specificity of $80 \%$ and $51.4 \%$, respectively (AUC $=0.71(95 \%$ CI $0.48-0.94)$ with $\mathrm{LR}+1.7, \mathrm{LR}-0.4$ and $p=0.05)$. Combining different variables with Alvarado score of $\geq 7$ points, the highest diagnostic accuracy of AA was provided by the set of predic-

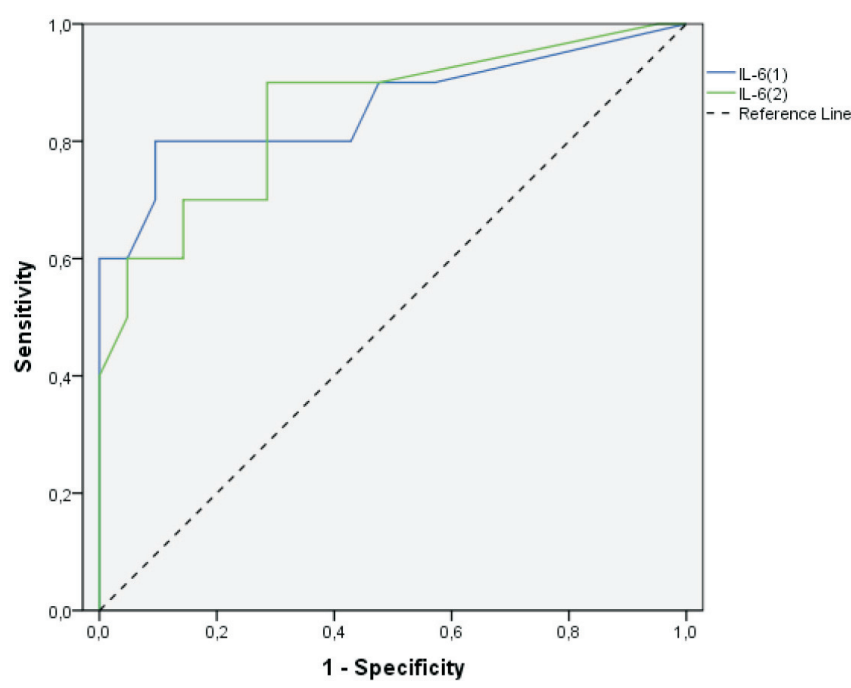

Fig. 2. ROC curve of IL-6 serum cytokine one hour before surgery and at the $24^{\text {th }}$ hour after surgery in patients with complicated AA, pg/mL.

IL-6(1) - cytokine concentrations one hour befor the operation; IL-6(2) cytokine concentrations $24 \mathrm{~h}$ after start of the operation

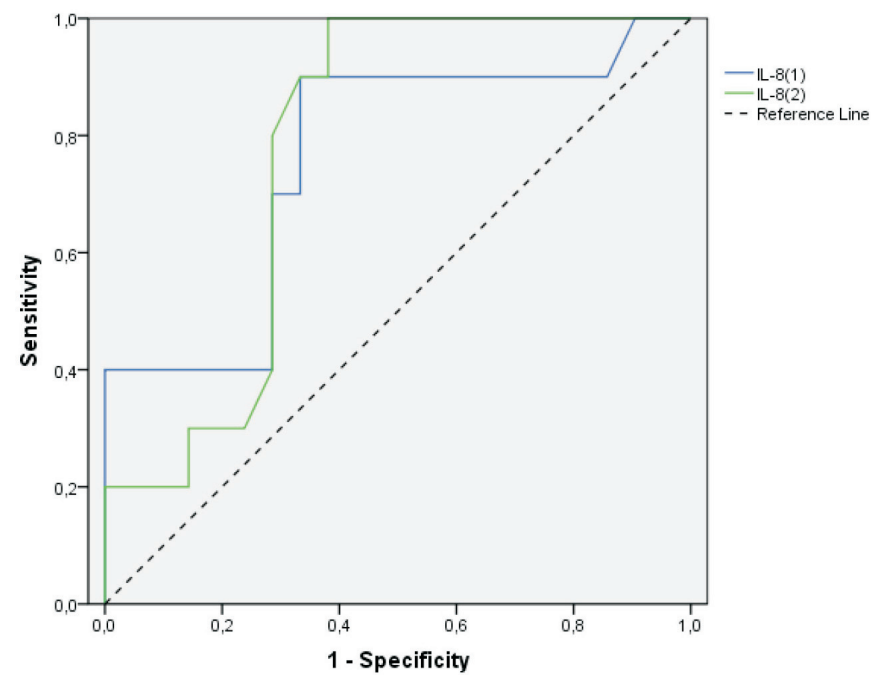

Fig. 3. ROC curve of IL-8 serum cytokine one hour before surgery and at the $24^{\text {th }}$ hour after surgery in patients with complicated AA, pg/mL.

IL-8(1) - cytokine concentrations one hour befor the operation; IL-8(2) cytokine concentrations $24 \mathrm{~h}$ after start of the operation

tors: Alvarado score of $\geq 7$ points, $\mathrm{WBC} \geq 10.7 \times 10^{3} / \mu \mathrm{L}$ and IL-6 $\geq 4.3 \mathrm{pg} / \mathrm{mL}(\mathrm{AUC}=0.89, \mathrm{LR}+1.9$ and LR- 0.1). More accurate detection of AA can be provided by an additional US examination of abdominal organs if patients are identified according to the criteria: Alvarado score of $\geq 7$ points and IL-6 $\geq 4.3 \mathrm{pg} / \mathrm{mL}$ with $100 \%$ specificity and PPV (Table 3).

\section{DISCUSSION}

Throughout the world, including Latvia, AA and AML are the most domineering emergent abdominal inflammatory processes in children requiring urgent diagnosis and treatment (Sikorska-Wisniewski et al., 2006; Dinu and Moraru, 2011; Surn et al., 2011; Brćtucu et al., 2013). From the 
QUALITY OF ALVARADO SCORE WITH ADDITIONAL VARIABLES IN AA DIAGNOSIS

\begin{tabular}{|c|c|c|c|c|c|c|c|}
\hline \multirow[t]{2}{*}{ Variables } & Sensitivity & Specificity & PPV & NPV & Accuracy & \multirow[t]{2}{*}{ LR+ } & \multirow[t]{2}{*}{ LR- } \\
\hline & \multicolumn{5}{|c|}{$\%,(95 \% \mathrm{CI})$} & & \\
\hline \multicolumn{8}{|c|}{2 predictors: $\mathrm{AS} \geq 7$ points and additional variables } \\
\hline IL-6 $\geq 4.3 \mathrm{pg} / \mathrm{mL}$ & $77.2(23.7-76.3)$ & $66.7(60.0-92.3)$ & $89.5(26.7-81.1)$ & $44.4(18.9-73.3)$ & $71.0(53.4-83.9)$ & 2.3 & 0.3 \\
\hline US & $63.6(43.0-80.3)$ & $66.7(30.0-90.3)$ & $87.5(64.0-96.5)$ & $33.3(13.8-60.9)$ & $64.3(45.8-79.3)$ & 1.9 & 0.5 \\
\hline $\mathrm{WBC} \geq 10.7 \times 10^{3} / \mu \mathrm{L}$ & $90.9(72.2-97.5)$ & $16.7(3.0-56.4)$ & $80.0(60.9-91.1)$ & $33.3(6.1-79.2)$ & $75.0(56.6-87.3)$ & 1.1 & 0.5 \\
\hline $\mathrm{CRP} \geq 8.4 \mathrm{mg} / \mathrm{L}$ & $54.5(34.7-73.1)$ & $33.3(9.7-70.0)$ & $75.0(50.5-89.8)$ & $16.7(4.7-44.8)$ & $50.0(32.6-67.4)$ & 0.8 & 1.4 \\
\hline \multicolumn{8}{|c|}{3 predictors: $\mathrm{AS} \geq 7$ points and IL- $6 \geq 4.3 \mathrm{pg} / \mathrm{mL}$ and additional variables } \\
\hline $\mathrm{WBC} \geq 10.7 \times 10^{3} / \mu \mathrm{L}$ & $94.1(73.0-99.0)$ & $50.0(9.5-90.5)$ & $94.1(73.0-99.0)$ & $50.0(9.5-90.5)$ & $89.5(68.6-97.1)$ & 1.9 & 0.1 \\
\hline US & $64.7(41.3-82.7)$ & $100(34.2-100)$ & $100(74.1-100)$ & $25.0(7.1-59.1)$ & $68.4(46.0-84.6)$ & - & 0.4 \\
\hline $\mathrm{CRP} \geq 8.4 \mathrm{mg} / \mathrm{L}$ & $47.1(26.2-69.0)$ & $50.0(9.5-90.5)$ & $88.9(56.5-98.0)$ & $10.0(1.8-40.4)$ & $47.6(27.3-68.3)$ & 0.9 & 1.1 \\
\hline
\end{tabular}

CI, confidence interval; LR, likelihood ratio; AS, Alvarado score; PPV, positive predictive value; NPV, negative predictive value; CRP, C reactive protein; WBC, white blood cell count, IL, 6 - interleukin 6; US - ultrasonography

1930s, epidemiological data in the US and Europe have displayed decreasing trends in the incidence of AA; nevertheless, AA is still one of the most common reasons for surgical acute abdominal pain in these regions (Kang et al., 2003). Retrospective analysis of the epidemiological situation of AA in Latvia from 2004 to 2009 showed a decline by $23.4 \%$ of patients with AA in the age group from 0 to 17 years (Surna et al., 2011). There are various clinical diagnostic scores of AA in children (Dingemann and Ure, 2012; Peyvasteh et al., 2017). The Alvarado score and PAS are the most widely used diagnostic scores of AA in children with proven high levels of diagnostic accuracy (Kharbanda et al., 2017; Dokumcu et al., 2018). However, these scores are based on retrospective studies, and thus diagnostic accuracy might be different in prospective studies (Pogorelić et al., 2015). The Alvarado and PAS scores have not been analysed or applied in Latvia. The present prospective study showed that some Alvarado score criteria (nausea, vomiting, and peritoneal irritation symptoms) are statistically significantly more common in AA patients (in more than half of the patients) than in AML patients. However, statistical significance for other Alvarado score features, such as pain of migration to lower right quadrant ( LRQP), temperature $\geq 37.3^{\circ} \mathrm{C}$, leukocytosis $\left(\geq 10 \times 10^{3} / \mu \mathrm{L}\right)$ and leukocyte deviation to the left, was not observed. The selected treatment of a patient depends on the value of the Alvarado score (Memon et al., 2013). The present study has showed that an Alvarado score of $\geq 7$ points is one of the criteria to distinguish patients with AA and AML with $73.7 \%$ accuracy. In a previous study of 69 patients with AA and 38 with AML, an Alvarado score of $\geq 7$ points was evaluated with $79 \%$ accuracy, $70 \%$ sensitivity, $71 \%$ specificity, $81 \%$ PPV and $56 \%$ NPV (Toorenvliet et al., 2011). Our study showed that an Alvarado score of $\geq 7$ points was associated with similar sensitivity, specificity, PPV and NPV, respectively, 71\%, $76.9 \%, 78.6 \%$ and $21.4 \%$. However, Alvarado score would not be sufficiently precise as the only diagnostic tool in choosing future tactics for patients with AA and AML. If the Alvarado score with value $o \geq 7$ points is the only method used to differentiate AA patients from AML, it can lead to an increase of false-negative cases. The present study revealed a group of factors that can help to discriminate patients with AA from AML patients much earlier and more accurately: Alvarado score of $\geq 7$ points, $\mathrm{WBC} \geq 10.7$ $\times 10^{3} / \mu \mathrm{L}$ and IL-6 $\geq 4.3 \mathrm{pg} / \mathrm{mL}$, resulting in sensitivity of $94.1 \%$, PPV $94.1 \%$, specificity $50 \%$, NPV $50 \%$ and overall diagnostic accuracy $89.5 \%$. Using these criteria, AA can be diagnosed in $94.1 \%$ of the cases. In cases where all of these criteria are not met in patients with AA, then $50 \%$ of the cases would have to be considered with false-negative results. If either IL-6, or WBC or Alvarado score is selected for AA diagnosis, then the individual diagnostic accuracy would be lower than $89.5 \%$. Regarding cut-off values in differential diagnosis for AA and AML, the cut-off value was $4.3 \mathrm{pg} / \mathrm{ml}$ for IL-6 with AUC of 77\%, achieving 67.7\% sensitivity and $76.9 \%$ specificity. This illustrates that IL-6 with this cut-off value is one of the earliest diagnostic indicators to be applied to differentiate AA patients from AML patients. However, individual measurement of IL-6 in patients with AA and AML has a lower diagnostic accuracy in comparison to using all three abovementioned criteria altogether. The cut-off value for WBC concentration in blood is $10.7 \times 10^{3} / \mu \mathrm{L}$, with AUC value $72 \%$ in ROC analysis, sensitivity $74.2 \%$ and specificity $53.8 \%$. Comparing the diagnostic accuracy of cut-off values in cases of AA and AML, IL-6 is more specific than WBC for AA because it reduces the possibility of false-positive case detection. This study showed that the accuracy of each diagnostic criterion separately was lower than the diagnostic accuracy of the all criteria together. The present results are partly consistent with data from another study of 49 children with AA and 11 children with AML, in which the IL-6 cut-off value was estimated to be $5.4 \mathrm{pg} / \mathrm{mL}$ with AUC value $77 \%$, including $73.5 \%$ sensitivity and $69.7 \%$ specificity, and the WBC cut-off value was $11.6 \times 103 / \mathrm{ml}$ with AUC value $68 \%$, $73.5 \%$ sensitivity and $65.6 \%$ specificity (Groselj-Grenc et al., 2007). The most important criteria to be taken into account for the accurate diagnosis of AA is Alvarado score of 
$\geq 7$ points, $\mathrm{WBC} \geq 10.7 \times 10^{3} / \mu \mathrm{L}$ and IL- 6 with the value of $4.3 \mathrm{pg} / \mathrm{mL}$. In this situation, the patient would need consultation with a paediatric surgeon and hospitalisation for the further treatment of AA. At this diagnostic phase AA can be clinically accurately distinguished from AML without the use of additional visual diagnostics to clarify the diagnosis. An algorithm that includes a combination of these criteria has been developed based on the results of the study. The algorithm also anticipates situations where AA diagnostic accuracy can be reduced if any of these three criteria changes in relation to the other two criteria. The present study showed that about half of the patients are not diagnosed with AA in situations when the criteria do not match. Additional examination of patients with AML and AA could help reduce these false-negative interpretations of AA. Therefore, the next step in the algorithm is to choose a diagnostic method with accuracy above $70 \%$, making it possible to differentiate AML from AA. One of such methods used in our study was US examination of abdominal organs with a compression test, which showed $71.9 \%$ diagnostic accuracy. In a similar type of study has been conducted in Iran, where 67 patients were examined with LRQP and underwent appendectomy, diagnostic accuracy was $72.4 \%$ after US examination of abdominal organs with a compression test (Nasiri et al., 2012). Another study using US examination had accuracy of $92 \%$, establishing strict criteria of US (Sayed et al., 2017). However, in the present study found, US examination accuracy was lower: sensitivity $67.7 \%$, with specificity $76.9 \%$ and accuracy $71.9 \%$. In a study conducted in the US study on USG examination of children with suspected AA, with data obtained from ten paediatric tertiary care centres, the estimated sensitivity of US in AA cases depended on the availability of the examination in a $24-\mathrm{h}$ period. In hospitals where USG was provided within 24 hours, the sensitivity of the method reached $77.7 \%$. In hospitals where US examination was available only during the day, the sensitivity of the US method decreased to only $51.6 \%$ (Mittal et al., 2013). In our study, the State Ltd CCUH lacked sufficient resources to provide 24/7 high quality US programmes and examinations that would provide more accurate diagnosis of AA. The US examination results also depend on the number of radiologists involved in the data evaluation and on the specialist's qualification and experience in the US method. This study revealed the importance of the US as an individual examination method in AA cases, not only due to $70 \%$ of PPV, but also as its diagnostic precision grew in combination with an Alvarado score of $\geq 7$ points and IL-6 with a cut-off vale in serum $4.3 \mathrm{pg} / \mathrm{mL}$, reaching $100 \%$ PPV. There are not many scientific studies that have analysed AA and AML differential diagnostic features in children, mostly because AA is compared with all other abdominal diseases characterised by acute LRQP. However, it is more challenging to differentiate AA from AML than to have AA cases compared to other emergency abdominal inflammatory processes. It should be emphasized that AA and AML are diseases that clinically simulate each other and at the same time also accompany one another. Thus, AML may be present as a separate disease, and also as a secondary cause of
AA case; therefore, it is difficult to distinguish them accurately with imaging diagnostics (Cobben et al, 2000; Macari et al., 2002). IL-6 and IL-10 concentrations were significantly higher in the case of AA than in the case of AML, but ROC analysis showed a statistically significant cut-off value only for IL-6. Comparison of uncomplicated and complicated AA cases showed that in the first serum sample, the concentration of IL-6, IL- 8 and MCP-1 was significantly higher in patients with complicated AA. Patients with uncomplicated AA had IL-6 and IL-8 median serum concentration of $5.4 \mathrm{pg} / \mathrm{mL}$ and $8.0 \mathrm{pg} / \mathrm{ml}$, but patients with complicated AA had median concentrations of $257.8 \mathrm{pg} / \mathrm{mL}$ and $36.2 \mathrm{pg} / \mathrm{mL}$. These results are consistent with reported IL- 6 and IL- 8 concentrations in uncomplicated and complicated AA cases in other studies: median IL- 6 and IL- 8 concentration of $21 \mathrm{pg} / \mathrm{mL}$ and $13.5 \mathrm{pg} / \mathrm{mL}$ in an uncomplicated AA group; and, respectively, $122.3 \mathrm{pg} / \mathrm{mL}$ and 25.2 $\mathrm{pg} / \mathrm{mL}$ in a complicated AA group (Kharbanda et al., 2011). The MCP-1 concentration was shown to increase at the postoperative phase in patients with uncomplicated AA after laparoscopic appendectomy rather than after conventional appendectomy, which was explained by carbon dioxide and irritation Gr- microbial effects on the peritoneal endothelial cells that secrete MCP-1 (Targarona et al., 2006; Serour et al., 2010). Our study found elevated MCP-1 serum concentration only in cases of AA, but clinical observations in other studies describe MCP-1 synthesis and its increasing concentration in the abdominal fluid (Riese et al., 2004). Local MCP-1, IL-6 and IL-8 synthesis in endothelial cells in the peritoneal abdominal fluid respond to the activity of Gr-microorganisms, promoting the formation of post-operative septic complications (Riese et al., 2004; El-Toukhy and Emam, 2016). This can explain the significant increase of IL-6, IL-8 and MCP-1 concentrations in complicated cases of AA in comparison to uncomplicated AA. Use of developed forecasting and action algorithm for AA needs bear in mind that the determination of inflammatory markers to identify AA cases depends on the patient's disease duration and obtained concentration cut-off values that distinguish uncomplicated AA groups of patients from complicated AA patients. In this way the likelihood of AA can be predicted for children who do not meet the Alvarado score of $\geq 7$ points, WBC $\geq 10.7 \times 10^{3} / \mu \mathrm{l}$ IL-6 and 4.3 $\mathrm{pg} / \mathrm{mL}$. Not only our study, but also others have shown elevated IL- 8 and MCP-1 concentrations in early AA cases (from 0 to $12^{\text {th }}$ hour of disease), which continue to increase in complicated AA cases up to the $48^{\text {th }}$ hour of the disease (Kharbanda et al., 2011). Serum IL-8 with a cut-off value of $\geq 12.3 \mathrm{pg} / \mathrm{mL}$ and MCP-1 with a cut-off value of $\geq 400.2$ $\mathrm{pg} / \mathrm{mL}$ showed the presence of complicated AA, regardless of disease duration. IL- 6 concentration in serum from the $13^{\text {th }}$ hour of the disease with a cut-off value of $\geq 39.2$ $\mathrm{pg} / \mathrm{mL}$ and CRP with $\geq 8.4 \mathrm{mg} / \mathrm{L}$ confirmed the diagnosis of complicated AA. One of the main factors hindering or limiting the study is the inclusion of a suitable number of cases according to the studied frequency of disease pathology. The first limiting factor for patient inclusion in the study was the lack of accessibility to abdominal US in the examination period from eight o'clock in the evening until eight 
o'clock in the morning. The second factor was related to SIMGC determination in blood samples according to the study protocol and completion of a patient's consent form. Since the study was designed to obtain three additional venous blood samples from the peripheral vein in order to determine SIMGC at different time intervals, then in some cases parents would change their mind about participation in the study or did not agree at the very beginning. Another key limiting factor was the possibility for patient check-up after the acute treatment period. In this study, the group of AML patients was not invited for check-up visits to completely exclude any AA cases after being discharged from the hospital. While considering the abovementioned limitations of the study, it does provide new knowledge for paediatric surgery in Latvia, as SIMGC and cut-off value serum criteria have not been previously used in combination with other examination techniques to improve its diagnostic accuracy of AA in children. Paediatric surgeons are interested in finding optimal methods to examine children with suspicion of AA in order to reduce undiagnosed cases of AA and their complications as well as reduce the number of negative appendectomy in Latvia.

\section{CONCLUSIONS}

Modified AS with specific serum cytokines are a reliable tool for initial differential diagnosis between AA and AML in school-age children. Based on the obtained results, AS $\geq 7$, WBC $\geq 10.7 \times 10^{3} / \mu \mathrm{L}$ and serum IL- $6 \geq 4.3 \mathrm{pg} / \mathrm{mL}$ together are criteria that yield higher sensitivity for AA. For further advanced diagnostics, we propose to take into account the serum IL-6, IL-8, MCP-1, CRP cut-off levels in the differential diagnosis between complicated and uncomplicated AA to decide whether the treatment will be conservative or surgical.

\section{ACKNOWLEDGEMENTS}

The study was financially supported by a Grant No. 2010.10-4/VPP-4 of the framework of the Latvian National Programme and Grant No. 2009/0147/1DP/1.1.2.1.2/09/ IPIA/VIAA/009 from the project Support for Doctoral and Post-doctoral Investigations Rīga Stradiņš University fellowship.

\section{REFERENCES}

Bachur, R. G., Hennelly, K., Callahan, M. J., Chen, C., Monuteaux, M. C. (2012). Diagnostic imaging and negative appendectomy rates in children: Effects of age and gender. Pediatrics, 129 (5), 877-884.

Cobben, L. P., Otterloo, A. M., Puylaert, J. B. (2000). Spontaneously resolving appendicitis: Frequency and natural history in 60 patients. Radiology, 215 (2), 349-352.

Dingemann, J., Ure, B. (2012). Imaging and the use of scores for the diagnosis of appendicitis in children. Eur. J. Pediatr. Surg., 22 (3), 195-200.

Dinu, C. A., Moraru, D. (2011) The etiological aspects of acute abdominal pain in children. Rev. Med. Chir. Soc. Med. Nat. Iasi., 115 (4), 1018-1023.

Dokumcu, Z., Kurtmen, B.T., Divarci, E., Tamay, P. B., Kose, T., Sezak, M., Ozok, G., Ergun, O., Celik, A. (2018). Retrospective multivariate analysis of data from children with suspected appendicitis: A new tool for diagnosis. Emerg. Med. Int., Volume 2018, Sep 12.

El-Toukhy, N., Emam, S. M. (2016). Diagnostic and prognostic values of monocyte chemotactic protein-1 in ascitic fluid of patients with spontaneous bacterial peritonitis. Egypt. J. Immunol., 23 (2), 17-27.

Groselj-Grenc, M., Repse, S., Dolenc-Strazar, Z., Hojker, S., Derganc, M. (2007). Interleukin-6 and lipopolysaccharide-binding protein in acute appendicitis in children. Scand. J. Clin. Lab. Invest., 67 (2), 197-206.

Kang, J. Y., Hoare, J., Majeed, A., Williamson, R. C., Maxwell, J. D. (2003). Decline in admission rates for acute appendicitis in England. Brit. J. Surg., 90 (12), 1586-1592.

Kharbanda, A. B., Cosme, Y., Liu, K., Spitalnik, S. L., Dayan, P. S. (2011). Discriminative accuracy of novel and traditional biomarkers in children with suspected appendicitis adjusted for duration of abdominal pain. Acad. Emerg. Med., 18 (6), 567-574.

Kharbanda, A. B., Monuteaux, M. C., Bachur, R. G., Dudley, N. C., Bajaj, L., Stevenson, M. D., Macias, C. G., Mittal, M. K., Bennett, J. E., Sinclair, K., Dayan, P. S. (2017). A clinical score to predict appendicitis in older male children. Acad. Pediatr., 17 (3), 261-266.

Macari, M., Hines, J., Balthazar, E., Megibow, A. (2002). Mesenteric adenitis: CT diagnosis of primary versus secondary causes, incidence, and clinical significance in pediatric and adult patients. Amer. J. Roentgenol., 178 (4), 853-858.

Memon, Z. A., Irfan, S., Fatima, K., Iqbal, M. S., Sami, W. (2013). Acute appendicitis: Diagnostic accuracy of Alvarado scoring system. Asian J. Surg., 36, 144-149.

Mittal, M. K., Dayan, P. S, Macias, C. G., Bachur, R. G., Bennett, J., Dudley, N. C., Bajaj, L., Sinclair, K., Stevenson, M. D., Kharbanda, A. B., Pediatric Emergency Medicine Collaborative Research Committee of the American Academy of Pediatrics. (2013). Performance of ultrasound in the diagnosis of appendicitis in children in a multicenter cohort. Acad. Emerg. Med., 20 (7), 697-702.

Myers, A. L., Williams, R. F., Giles, K., Waters, T. M., Eubanks, J. W., Hixson, S. D., Huang, E. Y., Langham, M. R., Blakely, M. L. (2012). Hospital cost analysis of a prospective, randomized trial of early vs interval appendectomy for perforated appendicitis in children. J. Amer. Coll. Surg., 214 (4), 427-434.

Nasiri, S., Mohebbi, F., Sodagari, N., Hedayat, A. (2012). Diagnostic value of ultrasound and the modified Alvarado scoring system in acute appendicitis. Int. J. Emerg. Med., 5, 26-30.

Õzdamar M. Y., Karavar, E. (2018). Acute mesenteric lymphadenitis in children: Findings related to differential diagnosis and hospitalization. Arch. Med. Sci., available from: https://doi.org/10.5114/aoms.2018.79430 (accessed 20.05.2019).

Peacok, J. L., Peacok, P. J. (eds.) (2011). Oxford Handbook of Medical Statistics. Oxford University Press. 517 pp.

Peyvasteh, M., Askarpour, S., Javaherizadeh, H., Besharati, S. (2017). Modified Alvarado score in children with diagnosis of appendicitis. Arq. Bras. Cir. Dig., 30 (1), 51-52.

Pogorelić, Z., Rak, S., Mrklić, I., Jurić, I. (2015). Prospective validation of Alvarado score and Pediatric Appendicitis Score for the diagnosis of acute appendicitis in children. Pediatr. Emerg. Care, 31 (3), 164-168.

Riese, J., Niedobitek, G., Lisner, R., Jung, A., Hohenberger, W., Haupt, W. (2004). Expression of interleukin-6 and monocyte chemoattractant protein- 1 by peritoneal sub-mesothelial cells during abdominal operations. $J$. Pathol., 202 (1), 34-40.

Sayed, A. O., Zeidan, N. S., Fahmy, D. M., Ibrahim, H. A. (2017). Diagnostic reliability of pediatric appendicitis score, ultrasound and low-dose computed tomography scan in children with suspected acute appendicitis. Ther. Clin. Risk Manag., 13, 847-854.

Serour, F., Herman, A., Babai, I., Gorenstein, A., Gershon, N., Somekh, E., Dalal, I. (2010). Evaluation of a possible inflammatory response after ap- 
pendectomy for non-perforated appendicitis in children. Eur. J. Pediatr. Surg., 20 (10), 29-34.

Sikorska-Wiśniewska, G., Liberek, A., Góra-Gebka, M., Bako, W., Marek, A., Szlagatys-Sidorkiewicz, A., Jankowska, A. (2006). Mesenteric lymphadenopathy - a valid health problem in children. Med. Wieku Rozwoj., 10 (2), 453-462.

Surna, D., Engelis, A., Petersons, A. (2011). Acute appendicitis in children in Latvia during 2000-2009: Overview of epidemiological situation [Akūts apendicīts bērniem Latvijā laika posmā no 2000. līdz 2009. gadam: epidemioloğiskās situācijas izmainu statistiskā analīze]. RSU Research Articles in Medicine \& Pharmacy [Rīga Stradiņš University Zinātniskie raksti], 2, 96-106 (in Latvian).
Targarona, E. M., Rodríguez, M., Camacho, M., Balagué, C., Gich, I., Vila, L., Trias, M. (2006). Immediate peritoneal response to bacterial contamination during laparoscopic surgery. 20 (2), 316-321.

Toorenvliet, B., Vellekoop, A., Bakker, R., Wiersma, F., Mertens, B., Merkus, J., Breslau, P., Hamming, J. (2011). Clinical differentiation between acute appendicitis and acute mesenteric lymphadenitis in children. Eur. J. Pediatr. Surg., 21 (2), 120-123.

Ünlüer, E. E., Urnal, R., Eser,, U., Bilgin S., Hacżyanlż, M., Oyar, O., Akošlu, H., Karagöz, A. (2016). Application of scoring systems with point-of-care ultrasonography for bedside diagnosis of appendicitis. World J. Emerg. Med., 7 (2), 124-129.

Received 18 October 2018

Accepted in the final form 28 May 2019

\section{LABORATORISKIE IZMEKLĒJUMI UN ALVARADO SKALA AKŪTA APENDICĪTA DIAGNOSTIKĀ SKOLAS VECUMA BËRNIEM}

Pētījuma mērķis bija noteikt Alvarado skalas (AS) un laboratorisko izmeklējumu diferenciāli diagnostisko nozīmi akūta apendicīta (AA) un akūta mezenteriāla limfadenīta (AML) gadījumā bērniem. Prospektīvi tika analizēti dati par 57 pacientiem (7-18 gadi), kuri stacionēti Bērnu klīniskajā universitātes slimnīcā ar aizdomām par AA laika posmā no 2010. oktobra līdz 2013. gada oktobrim. Apendektomija tika veikta 31 pacientam ar AA. 26 pacientiem ķirurğiska ārstēšana netika veikta, jo ultrasonogrāfijā tika konstatēts AML. Stacionēšanas brīdī visi pacienti tika novērtēti un salīdzināti starp pētījuma grupām pēc AS kritērijiem, kā arī asinīs noteiktiem citokīnu grupas seruma iekaisuma mediatoriem (EGF, IL-10, IL-12 (p70), IL-1ß, IL-4, IL-6, IL-8, IL-17, MCP-1, TNF- $\alpha$ ), C - reaktīvā olbaltuma (CRO) un kopējā leikocītu skaita (WBC). Pētījumā iesaistīto 57 pacientu vidējais vecums bija 12,9 gadi (SD 3,2). AA gadījumā visbiežāk tika novērota AS vērtība $\geq 7$ ballēm ar testa precizitāti 73,7\% (95\% TI 61,0-83,4; $p=0,001$ ). Pacientiem ar AA tika konstatētas ticamas WBC un seruma IL-6 koncentrāciju atšķirības salīdzinājumā ar AML pacientiem. Visaugstākā AA diagnostiskā precizitāte tika konstatēta pie AS $\geq 7$ kombinācijā ar $\mathrm{WBC} \geq 10,7 \times 10^{3} / \mu \mathrm{L}$ un IL-6 $\geq 4.3 \mathrm{pg} / \mathrm{mL}$ (AUC $=0,89$, jutîba 94,1\% un specifitāte 50\%). Veicot padziḷinātu iekaisuma mediatoru datu analīzi, tika ṇemtas vērā IL-6, IL-8, MCP-1 un CRO koncentrāciju robežvērtības serumā pirms uzsāktās ārstēšanas, lai diferencētu pacientus ar nekomplicētu un komplicētu AA. Nosakot vismaz vienu no minētajiem citokīnu grupas seruma iekaisuma mediatoriem ar noteiktu koncentrācijas robežvērtību, iespējams precīzāk definēt indikācijas konservatīvai vai kirurğ́iskai ārstēšanai pacientiem ar AA. 